\title{
Regular Treatment Strategy with a Large Amount of Carvedilol for Heart Failure Improves Biventricular Systolic Failure in a Patient with Repaired Tetralogy of Fallot
}

\author{
Katsura Soma, ${ }^{1} \mathrm{MD}$, Atsushi Yao, ${ }^{2} \mathrm{MD}$, Akihito Saito, ${ }^{1} \mathrm{MD}$, Toshiro Inaba, ${ }^{1} \mathrm{MD}$, Yuichi Ishikawa, ${ }^{3} \mathrm{MD}$, \\ Yasutaka Hirata, ${ }^{4} \mathrm{MD}$ and Issei Komuro, ${ }^{1} \mathrm{MD}$
}

\begin{abstract}
Summary
It is widely known that $\beta$-blockers exert beneficial effects on non-ischemic and ischemic systolic heart failure (sHF) in nonstructural hearts. However, whether $\beta$-blockers exert similar effects on sHF associated with congenital heart disease (CHD), particularly in an anatomical right ventricle, remains under debate.

Here we report the case of an adult man with repaired tetralogy of Fallot suffering from biventricular heart failure. Treatment with carvedilol directly improved the systolic function of the right and left ventricles. This case report strongly suggests there is potential for carvedilol to exert a beneficial effect on heart failure in CHD. The appropriate titration of carvedilol and patient follow-up for long-term effects are important when treating adult patients with CHD with $\beta$-blockers.
\end{abstract}

(Int Heart J 2018; 59: 1169-1173)

Key words: Right ventricular failure, $\beta$-blockers, Adult congenital heart disease, Cardiac MRI

$\mathrm{C}$ arvedilol is a standard medication for chronic systolic heart failure in patients with nonstructural heart disease. ${ }^{1,2)}$ However, it remains unclear whether carvedilol is effective in systolic heart failure (sHF), especially right heart failure associated with CHD. ${ }^{3}$ A 49-year-old male patient who had undergone an intracardiac repair for tetralogy of Fallot (TOF) at the age of 5 years developed severe biventricular systolic failure, which was a contraindication for additional surgical repair for right ventricular outflow tract restenosis (RVOTS) and residual ventricular septal defect (VSD). Therapy with carvedilol markedly improved the patient's biventricular function, enabling the patient to undergo surgical repair. Cardiac magnetic resonance imaging revealed the improvement in right ventricular (RV) function occurred long after that in left ventricular (LV) function, suggesting that carvedilol exerted individual beneficial effects on each ventricle.

\section{Case Report}

A 49-year-old man was admitted to our hospital with dyspnea (New York Heart Association functional class III [NYHA-FC III]) and prominent pretibial edema. He had undergone an intracardiac repair of TOF in 1974 when he was 5 years of age. At the age of 42 years, he was diagnosed with premature ventricular contractions without sus- tained tachycardia (approximately 3000 times/day) and sought assistance at a university hospital for a detailed examination, including catheterization, which showed RV and LV dilatation associated with $\mathrm{sHF}$ and significant RVOTS with a trans-RVOTS-pressure gradient (T-RVOTSPG) of $58 \mathrm{mmHg}$ calculated from a systolic right ventricular pressure of $80 \mathrm{mmHg}$ and systolic pulmonary arterial pressure of $22 \mathrm{mmHg}$. The patient was informed that another surgical repair for the RVOTS was required, but he refused to have the procedure. On admission to our hospital, his height and weight were $167 \mathrm{~cm}$ and $68 \mathrm{~kg}$, respectively. His blood pressure was $124 / 90 \mathrm{mmHg}$, his heart rate (HR) was regular at 97 beats per minute, and the oxygen saturation of his arterial blood measured by pulse oximeter was $98 \%$ on room air. A chest radiograph showed moderate cardiomegaly (cardiothoracic ratio 58\%) with lung congestion. An electrocardiogram showed sinus rhythm with a complete right bundle branch block and QRS duration of $202 \mathrm{msec}$. Laboratory tests revealed the brain natriuretic peptide (BNP) level had increased to $1014 \mathrm{pg} / \mathrm{mL}$ and the serum creatinine, gamma-glutamyl transpeptidase, and urinary acid levels were slightly elevated $(1.14 \mathrm{mg} / \mathrm{dL}, 77 \mathrm{U} / \mathrm{L}$, and $8.8 \mathrm{mg} / \mathrm{dL}$, respectively), while all other lab values were normal. A transthoracic echocardiogram showed a dilated RV and LV with reduced systolic function. Trivial pulmonary regurgitation and trivial aortic regurgitation were documented, but there

From the ${ }^{1}$ Department of Cardiovascular Medicine, The University of Tokyo Hospital, Tokyo, Japan, ${ }^{2}$ Division for Health Service Promotion, The University of Tokyo, Tokyo, Japan, ${ }^{3}$ Department of Pediatric Cardiology, Fukuoka Children's Hospital, Fukuoka, Japan and ${ }^{4}$ Department of Cardiac Surgery, The University of Tokyo Hospital, Tokyo, Japan.

Address for correspondence: Atsushi Yao, MD, Division for Health Service Promotion, The University of Tokyo, 7-3-1 Hongo, Bunkyo-ku, Tokyo 1130033, Japan. E-mail: yaoa-int@h.u-tokyo.ac.jp

Received for publication September 8, 2017. Revised and accepted December 16, 2017.

Released in advance online on J-STAGE August 11, 2018.

doi: 10.1536/ihj.17-525

All rights reserved by the International Heart Journal Association. 

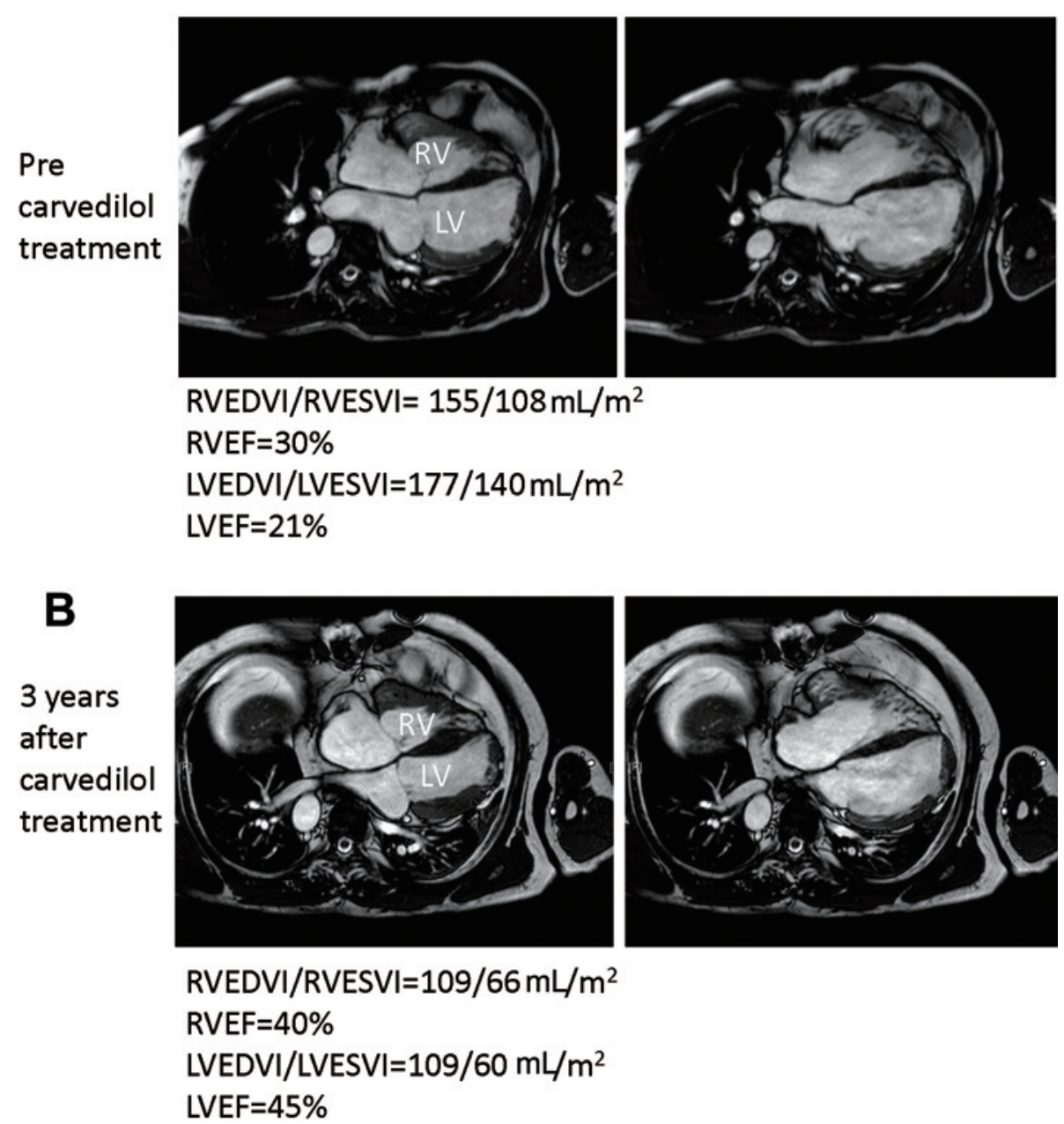

Figure 1. Four-chamber view of cMRI. A 4-chamber view of cMRI images at pretreatment and 3 years after carvedilol treatment are shown. Carvedilol significantly improved not only LVEF and LVEDVI, but also RVEF and RVEDVI. cMRI indicates cardiac magnetic resonance imaging; LVEDVI, left ventricular end-diastolic volume index; LVEF, left ventricular ejection fraction; RVEDVI, right ventricular end-diastolic volume index; and RVEF, right ventricular ejection fraction.

was no other detectable valvular regurgitation. Cardiac catheterization revealed the systemic blood flow index (QsI) was slightly decreased $\left(2.3 \mathrm{~L} /\right.$ minute $\left./ \mathrm{m}^{2}\right)$ with a small left-to-right shunt through the residual VSD $(\mathrm{Qp} / \mathrm{Qs}$ $=1.1$ ) and a peak-to-peak T-RVOTS-PG of $42 \mathrm{mmHg}$ resulting from a right ventricular systolic pressure of 63 $\mathrm{mmHg}$ and pulmonary arterial systolic pressure of 21 $\mathrm{mmHg}$. A coronary angiogram showed no significant coronary stenosis. Cardiac magnetic resonance imaging (cMRI) showed a markedly impaired ejection fraction (EF) and severe dilatation of both ventricles. The LVEF was $21 \%$ and RVEF was $30 \%$ (Figure 1). Episodes of tachyarrhythmia were not detected. Because of the poor biventricular systolic function, surgical repair of the RVOTS and VSD was contraindicated.

After stabilizing the patient's heart failure with diuretics, the BNP had decreased to $360 \mathrm{pg} / \mathrm{mL}$ and carvedilol was administered and carefully titrated up to $25 \mathrm{mg}$.
We set the target dose of carvedilol at $25 \mathrm{mg}$, because the $\mathrm{HR}$ has decreased and stabilized at 60-70 bpm. The cMRI showed near normalization of the LVEF (45\%) and the LV cavity $\left(\mathrm{LVEDVI}=109 \mathrm{~mL} / \mathrm{m}^{2}\right.$ ); however, the $\mathrm{RVEF}$ and the RV cavity showed little improvement (Figures 1, 2 ). The recovery of the RVEF was delayed but eventually reached $40 \%$. The improvement in LVEF primarily occurred within 1 year of initiating carvedilol; however, recovery of the RVEF took longer (Figure 2). The QsI normalized $\left(3.3 \mathrm{~L} /\right.$ minute $\left./ \mathrm{m}^{2}\right)$ while the T-RVOTS-PG, calculated from a systolic right ventricular pressure of 75 $\mathrm{mmHg}$ and systolic pulmonary arterial pressure of 16 $\mathrm{mmHg}$, increased to $59 \mathrm{mmHg}$. Eventually, the patient clinically improved to NYHA-FC II. Because of the marked improvement, the RVOTS and VSD could then be surgically repaired, and the patient agreed to undergo the operation. After surgical repair, his LVEF and RVEF improved further. 


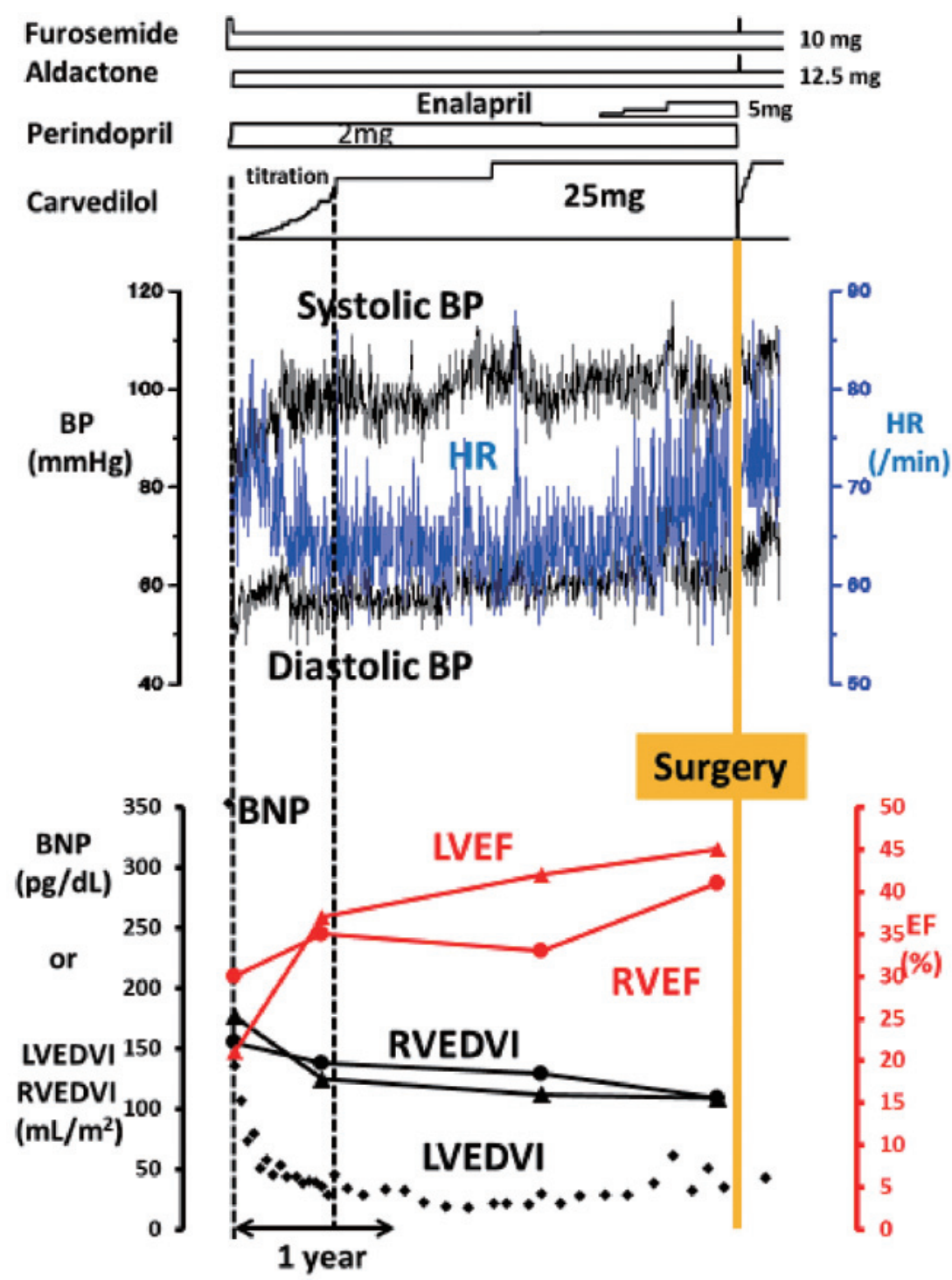

Figure 2. Clinical course. Data on home BP, home HR, BNP, LVEDVI and RVEDVI, and LVEF and RVEF are presented along with the dosage of the drugs administered to the patient. During the titration of carvedilol (between the two dotted lines), the HR apparently decreased and the systolic BP increased while the LVEF and the LVEDVI subnormalized. Note that the improvements in RVEF and RVEDVI occurred long after those in the LVEF and LVEDVI. BNP indicates brain natriuretic peptide BP, blood pressure; HR, heart rate; LVEDVI, left ventricular end-diastolic volume index; LVEF, left ventricular ejection fraction; RVEDVI, right ventricular end-diastolic volume index; and RVEF, right ventricular ejection fraction.

\section{Discussion}

This case report demonstrates the effects of carvedilol for biventricular $\mathrm{sHF}$ in a patient with repaired TOF. Although the improvement in LV systolic function might have directly contributed to the improvement in RV systolic function through an LV-RV interaction, most of the improvement in the RV occurred long after that in the LV, strongly suggesting that most of the RV recovery can be attributed to carvedilol.

The use of carvedilol for the treatment of sHF associated with CHD has not been established, especially in an anatomical right ventricle. We reviewed the English literature for studies in which $\beta$-blockers were used to treat heart failure in adults with a history of CHD and found 6 reports that are summarized in the Table. In these reports, there are discrepancies in the effectiveness of $\beta$-blockers for sHF and right heart failure in adults with $\mathrm{CHD}^{3,4)}$ The discrepancies could be attributed to etiological inhomogeneity in CHD, improper evaluation of ventricular function (particularly RV function), insufficient dosage of $\beta$ blocker, and/or short follow-up periods. ${ }^{3-9)}$ Of these 6 reports, only two showed the effectiveness of $\beta$-blockers on RVEF, ${ }^{6,8)}$ and in both studies the target disease was re- 
Table. Previous Studies Using $\beta$-Blockers for Adult Congenital Heart Diseases

\begin{tabular}{|c|c|c|c|c|c|c|c|}
\hline Study & Target disease & $n$ & Age & Study design & $\begin{array}{l}\text { Medication and } \\
\text { maximum dose }\end{array}$ & $\begin{array}{l}\text { Follow-up } \\
\text { duration }\end{array}$ & Outcome \\
\hline $\begin{array}{l}\text { JAMA 2007; } \\
\text { Shaddy, et al. }{ }^{2)}\end{array}$ & $\begin{array}{l}\mathrm{DCM} \text { and } \\
\text { various types of } \\
\text { CHD }\end{array}$ & 161 & $\begin{array}{l}<18 \text { years } \\
\text { Median } 3 \text { years }\end{array}$ & $\begin{array}{l}\text { RCT } \\
\text { Multicenter }\end{array}$ & $\begin{array}{l}\text { Carvedilol } \\
25 \mathrm{mg} / \text { day }\end{array}$ & 8 months & $\begin{array}{l}\text { No difference in LVEF and } \\
\text { BNP }\end{array}$ \\
\hline $\begin{array}{l}\text { Heart and Vessels } 2009 \text {; } \\
\text { Nishiyama, et al. }{ }^{3)}\end{array}$ & $\begin{array}{l}\mathrm{DCM} \text { and } \\
\text { various types of } \\
\text { CHD }\end{array}$ & 27 & $\begin{array}{l}23 \text { days to } 47 \\
\text { years }\end{array}$ & $\begin{array}{l}\text { Retrospective } \\
\text { observational } \\
\text { study }\end{array}$ & $\begin{array}{l}\text { Carvedilol } \\
0.8 \mathrm{mg} / \mathrm{kg} / \mathrm{day}\end{array}$ & 1-46 months & $\begin{array}{l}\text { CTR, LVEF, hANP and } \\
\text { BNP were improved }\end{array}$ \\
\hline $\begin{array}{l}\text { Am J Cardiol 2007; } \\
\text { Doughan, et al. }{ }^{4)}\end{array}$ & $\begin{array}{l}\text { TGA (systemic } \\
\text { right ventricle) }\end{array}$ & 60 & $29 \pm 6$ years & $\begin{array}{l}\text { Retrospective } \\
\text { observational } \\
\text { study }\end{array}$ & $\begin{array}{l}\text { Carvedilol } \\
50 \mathrm{mg} / \text { day } \\
\text { Metoprolol } \\
100 \mathrm{mg} / \text { day }\end{array}$ & $10 \pm 7$ months & $\begin{array}{l}\text { NYHA improved No } \\
\text { difference in RVEF and } \\
\text { RVEDV (echocardiogram) }\end{array}$ \\
\hline $\begin{array}{l}\text { Int J Cardiol 2007; } \\
\text { Giardini, et al. }{ }^{5 \text { ) }}\end{array}$ & $\begin{array}{l}\text { TGA (systemic } \\
\text { right ventricle) }\end{array}$ & 8 & 18-31 years & $\begin{array}{l}\text { Prospective } \\
\text { study }\end{array}$ & $\begin{array}{l}\text { Carvedilol } \\
50 \mathrm{mg} / \text { day }\end{array}$ & 1 year & $\begin{array}{l}\text { RVEDV, RVEF, and LVEF } \\
\text { were improved (cMRI) }\end{array}$ \\
\hline $\begin{array}{l}\text { Circ J 2011; } \\
\text { Ishibashi, et al. }{ }^{6} \text { ) }\end{array}$ & Single ventricle & 50 & $\begin{array}{l}1 \text { month to } \\
34 \text { years }\end{array}$ & $\begin{array}{l}\text { Prospective } \\
\text { study }\end{array}$ & $\begin{array}{l}\text { Carvedilol } \\
0.42 \pm 0.29 \\
\mathrm{mg} / \mathrm{kg} / \text { day }\end{array}$ & 11 months & EF was improved \\
\hline $\begin{array}{l}\text { Can J Cardiol 2006; } \\
\text { Josephson, et al. }{ }^{\text {7) }}\end{array}$ & $\begin{array}{l}\text { TGA (systemic } \\
\text { right ventricle) }\end{array}$ & 8 & 22-37 years & Case series & $\begin{array}{l}\text { Carvedilol } \\
25 \mathrm{mg} / \text { day } \\
\text { Metoprolol } \\
25 \mathrm{mg} / \text { day } \\
\text { Sotalol } \\
80 \mathrm{mg} / \text { day }\end{array}$ & $\begin{array}{l}3 \text { years (median) } \\
1-12 \text { years }\end{array}$ & $\begin{array}{l}\text { RVEF was improved } \\
\text { (cMRI) }\end{array}$ \\
\hline $\begin{array}{l}\text { Cardiol Young 2007; } \\
\text { Norozi, et al. }{ }^{8)}\end{array}$ & TOF & 33 & $30.9 \pm 9.5$ years & RCT & $\begin{array}{l}\text { Bisoprolol } \\
10 \mathrm{mg} / \text { day }\end{array}$ & 6 months & $\begin{array}{l}\text { No difference in pVO2, } \\
\text { RVEDV, RVEF, NYHA. } \\
\text { (echocardiogram and } \\
\text { cMRI) BNP increased }\end{array}$ \\
\hline
\end{tabular}

DCM indicates dilated cardiomyopathy; CHD, congenital heart disease; RCT, randomized controlled trial; TGA, transposition of the great arteries; TOF, tetralogy of Fallot; BNP, brain natriuretic peptide; CTR, cardio-thoracic ratio; NYHA, New York Heart Association; and pVO2, peak VO2.

stricted to one specific CHD, transposition of the great arteries (TGA), the dosage of carvedilol was seemingly sufficient, the follow-up durations were at least longer than one year, and the assessment of RVEF was done with cMRI. Moreover, in the case of TGA, a systemic right ventricle might be present due to chronic ischemic stress as well as pressure overload. ${ }^{6,8)}$

In our patient, the etiology of biventricular sHF was unclear, although ischemic stress might have been involved due to the use of an unestablished cardiopulmonary bypass system for open cardiac surgery in 1974. The patient's history of premature ventricular contractions can account for only a small portion of the etiology of the sHF. Also, the pressure overload from the T-RVOTS-PG would have, to some extent, contributed to acceleration of the RV failure. Based on the HR records (Figure 2), the final dose of carvedilol (25 mg) was apparently sufficient. $^{10,11)}$ Since cMRI is the gold-standard for volumetric and functional evaluation of the RV as well as the LV, ${ }^{12,13)}$ our assessment was quite reliable. Finally, long-term follow-up of the patient's biventricular function with cMRI provided detailed images of the recovery of the biventricular systolic failure and suggests that RV recovery in response to carvedilol might take longer than LV recovery.

In conclusion, carvedilol has the potential to improve biventricular systolic function in patients with $\mathrm{CHD}$; however, it may take 1-2 years for its beneficial effect to be detected. The dosage of $\beta$-blocker and the treatment duration are very important for improvement in sHF in adult CHD patients to occur. Additional studies should be con- ducted to confirm the beneficial effects of $\beta$-blockers and to evaluate which types of heart failure respond to $\beta$ blockers in patients with various types of CHD.

\section{Disclosures}

Conflicts of interest: None.

\section{References}

1. Packer M, Bristow MR, Cohn JN, et al. The effect of carvedilol on morbidity and mortality in patients with chronic heart failure. N Engl J Med 1996; 334: 1349-55.

2. Nitta D, Kinugawa K, Imamura T, Kato NP, Komuro I. High dose beta-blocker therapy triggers additional reverse remodeling in patients with idiopathic non-ischemic cardiomyopathy. Int Heart J 2016; 57: 717-24.

3. Shaddy RE, Boucek MM, Hsu DT, et al. Carvedilol for children and adolescents with heart failure: A randomized controlled trial. JAMA 2007; 298: 1171-9.

4. Nishiyama M, Park IS, Yoshikawa T, et al. Efficacy and safety of carvedilol for heart failure in children and patients with congenital heart disease. Heart Vessels 2009; 24: 187-92.

5. Doughan AR, McConnell ME, Book WM. Effect of beta blockers (carvedilol or metoprolol XL) in patients with transposition of great arteries and dysfunction of the systemic right ventricle. Am J Cardiol 2007; 99: 704-6.

6. Giardini A, Lovato L, Donti A, et al. A pilot study on the effects of carvedilol on right ventricular remodelling and exercise tolerance in patients with systemic right ventricle. Int $\mathrm{J}$ Cardiol 2007; 114: 241-6.

7. Ishibashi N, Park IS, Waragai T, et al. Effect of carvedilol on heart failure in patients with a functionally univentricular heart. 
Circ J 2011; 75: 1394-9.

8. Josephson CB, Howlett JG, Jackson SD, Finley J, Kells CM. A case series of systemic right ventricular dysfunction post atrial switch for simple D-transposition of the great arteries: the impact of beta-blockade. Can J Cardiol 2006; 22: 769-72

9. Norozi K, Bahlmann J, Raab B, et al. A prospective, randomized, double-blind, placebo controlled trial of beta-blockade in patients who have undergone surgical correction of tetralogy of Fallot. Cardiol Young 2007; 17: 372-9.

10. Bristow MR, Gilbert EM, Abraham WT, et al. Carvedilol produces dose-related improvements in left ventricular function and survival in subjects with chronic heart failure. MOCHA Investigators. Circulation 1996; 94: 2807-16.
11. Kato N, Kinugawa K, Imamura $\mathrm{T}$, et al. Trend of clinical outcome and surrogate markers during titration of beta-blocker in heart failure patients with reduced ejection fraction: relevance of achieved heart rate and beta-blocker dose. Circ J 2013; 77: 1001-8.

12. Blalock SE, Banka P, Geva T, Powell AJ, Zhou J, Prakash A. Interstudy variability in cardiac magnetic resonance imaging measurements of ventricular volume, mass, and ejection fraction in repaired tetralogy of fallot: A prospective observational study. J Mag Reson Imaging 2013; 38: 829-35.

13. Tandri H, Daya SK, Nasir K, et al. Normal reference values for the adult right ventricle by magnetic resonance imaging. Am J Cardiol 2006; 98: 1660-4 